\title{
RESPONSE OF RUTA GRAVEOLENS L. TO ROCK PHOSPHATE AND /OR FELDSPAR UNDER BIOLOGICAL FERTILIZERS
}

\author{
Khalid, Kh.A. ${ }^{1}$; Soheir, E. EL-Sherbeny ${ }^{1}$ and A.M. Shafei ${ }^{2}$
}

1. Cultivation and Production of Medicinal and Aromatic Plants Dept., National Research Center, Dokki, Cairo, Egypt

2. Soils \& Water Use Department, National Research Center, Dokki, Cairo, Egypt

Keywords: Ruta graveolens L., Rock phosphate, Feldspar, Biological potassium phosphorous fertilizer, Biological potassium fertilizer, Vegetative growth characters, Essential oil and chemical composition

\section{ABSTRACT}

Two experiments were consummated at the Experimental Farm, National Research Center (NRC), Dokki, Cairo, Egypt during two successive seasons of 2004/2005 and 2005/2006 to evaluate the effect of natural products as a source of some important elements such as rock phosphate as a source of phosphorous and feldspar mica as a source of potassium with biological potassium phosphorous fertilizer or biological potassium fertilizer (Silicate bacterium) at different levels $(0.0,25,50$ and $100 \mathrm{~g} / \mathrm{L})$ on Ruta graveolens $\mathrm{L}$. plant instead of the chemical fertilizes. Adding biological fertilizer with feldspar or rock phosphate improved vegetative growth characters such as plant height $(\mathrm{cm})$, branches number/ plant, fresh and dry weights of different plant parts i.e. leaves, stems and roots (g/plant), in addition to some chemical constituents as essential oil, total flavonoides, $\mathrm{P}, \mathrm{K}, \mathrm{Fe}, \mathrm{Zn}$ and $\mathrm{Cu}$ content. On the other hand, the main constituents of essential oil and $\mathrm{N}$ content were decreased compared with adding recommended chemical fertilizers.

\section{INTRODUCTION}

Rue, Ruta graveolens L. (Rutaceae), a traditional medicinal plant, known to prevent the attacks by fleas and other noxious insects. The plant is also used as a flavoring agent for spirits and foods. Previous research showed the inhibition of in vitro germination and the radical growth of radish seeds by an aqueous extract of rue and some of its constituents, in particular furanocoumarin derivatives (Aliotta et al 1994). These findings prompted some researchers to investigate the potential effect of rue extracts as an herbicide against the germination of some common weeds in the soil. The total extract of rue and some isolated compounds resulted in an active inhibition of weed germination, in particular Portulaca oleracea L., causing an irreversible damage to protruded radicals. Some constituents of this extract (furocoumarins and flavonols) also inhibited in vitro germination of several weeds (Aliotta $\boldsymbol{e t}$ al 1995 and 1996). The essential oil and some of its minor constituents were effective and dose dependent inhibitors of both the germination and radical growth of radish (Vincenzo et al 2002).

The green tissues of Ruta graveolens are a rich source of flavonol glycosides, for example rutin, and gossypetin glycosides and have been identified as the major floral pigments (Harborne \& Boardley 1983). Moreover rue is thus a valuable natural source of alkaloids such as acridones and furoquinoline alkaloids, which exhibit a wide range of physiological activities (Waterman and Grundon 1985).

Phosphorous plays an important role in various metabolism processes. It is a constituent of nucleic acid, phospholipids, the coenzymes, DNA and NADP, and most importantly ATP. It activates coenzymes for amino acid production used in protein synthesis, and it is decomposes carbohydrate production in photosynthesis; as well as involved many other metabolic processes required normal growth, such as photosynthesis, glycolysis, respi- 
ration, fatty acid synthesis. Moreover, phosphorous enhances seed germination and early growth, stimulates blooming, enhances bud set, aids in seed formation and hastens maturity (Espinnosa et al 1993). Potassium with phosphorous fertilizer increase the plant growth and essential oil content in some aromatic plants such as anise, coriander and sweet fennel (Khalid 1996).

Phosphorous is added to cultivated soil in different forms as mineral phosphate fertilizers or organic manure. The soluble $\mathrm{P}$ in these fertilizers is quickly turns into unavailable form for plant nutrition and this problem is well known in Egyptian soils specially those rich in calcium carbonate (El-Gamal, 1996).

Fortunately, soil microorganisms known as phosphate solubilizing microorganisms play a fundamental role in converting $\mathrm{P}$ fixed form to be soluble ready available for plant nutrition. The microbial breakdown of soil organic matter is associated with an increase organic, inorganic acids and $\mathrm{CO}_{2}$ production with possibly increases the solubility of soil phosphate (Goldstein, 1995).

Gomaa (1989) demonstrated that, some effects of phosphate solubilizing microorganisms inoculation have been observed in terms of increasing the amounts of available $\mathrm{P}$ and plant growth of crop production. Applying phosphate solubilizing microorganisms with calcium superphosphate improved growth, and chemical composition of Sinapis alba L. plants than calcium superphosphate fertilizer alone (Khalid, 2004).

Potassium is one of the most important elements for plant nutrition, which content occupies $1 \%-5 \%$ of crops dry weight, it plays a very important role in the growth, yield and quality of crops, Potassium is involved in the activities of over 60 kinds of plant enzymes, Potassium affects the metabolism of nitrogen and carbohydrates, and the synthesis of lipid, starch and protein. Potassium also plays a very important role in substance transportation inside plants. (Espinnosa et al 1993). Potassium nutrition increases the plant growth and essential oil content on marigold plants (Somida 2002).

Silicate bacterium or biological potassium fertilizer can activate the fixed potassium for plant nutrition, as well as prevention and control of plant diseases, also it can effectively prevent crops from early aging and have a strong resistance to drought, cold and lodging (Subba Rao, 1984). Zahra et al (1984) reported that, silicatedissolving bacteria played a pronounced role in the biological weathering of soil minerals and it can promote $\mathrm{K}$ and $\mathrm{Si}$ releasing from feldspar. Sheng et al 2003 showed that, silicate-dissolving bacteria could activate soil $\mathrm{P}, \mathrm{K}$, and micronutrients reserves and promote plant growth. Styriakova et al 2003 reported that, the activity of silicate dissolving played a pronounced role in release of $\mathrm{Si}, \mathrm{Fe}$ and $\mathrm{K}$ from feldspar and $\mathrm{Fe}$ oxyhydroxides.

However, due to the economic considerations, the cost of applying phosphate and potassium fertilizers is becoming more expensive. Thus, the use of alternative materials such as rock phosphate as a source of phosphorous fertilizer and feldspar as a source of potassium fertilizer are ganging importance the dependency of costly commercial fertilizers. On the other hand, rock phosphate have a very low grade of $\mathrm{P}$ a content, also feldspar is not available for direct application as plant nutrient because it low solubility when applied to the soil, so using potassium and phosphate solubilizing microorganisms with rock phosphate and feldspar very important to increasing the mobilization of $\mathrm{P}$ and $\mathrm{K}$ form rock phosphate and feldspar (Biswas and Narayanasamy 2002 \& Styriakova et al 2003).

In this study we evaluate the natural products as a source of some important elements on Ruta graveolens L. plant such as rock phosphate as a source of phosphorous and feldspar mica as a source of potassium with biological potassium phosphorous fertilizer and biological potassium fertilizer (Silicate bacterium) instead of the chemical fertilizes.

\section{MATERIALS AND METHODS}

Two experiments were carried out during two successive seasons of 2004/2005 and 2005/2006. The experiments were conducted at the Experimental Farm, National Research Center (NRC), Dokki, Cairo, Egypt to study the effect of rock phosphate and /or feldspar under biological fertilizers on growth characters and chemical constituents of Ruta graveolens L. plants.

Mechanical and chemical properties of the soil used in this study were determined according to Jackson 1973 and Cottenie et al 1982 and are presented in Table (1).

Certified seeds of Ruta graveolens $\mathrm{L}$ were kindly obtained from the Department of Medicinal and Aromatic plants, Ministry of Agriculture, Egypt. 
Table 1. Mechanical and chemical properties of the soil

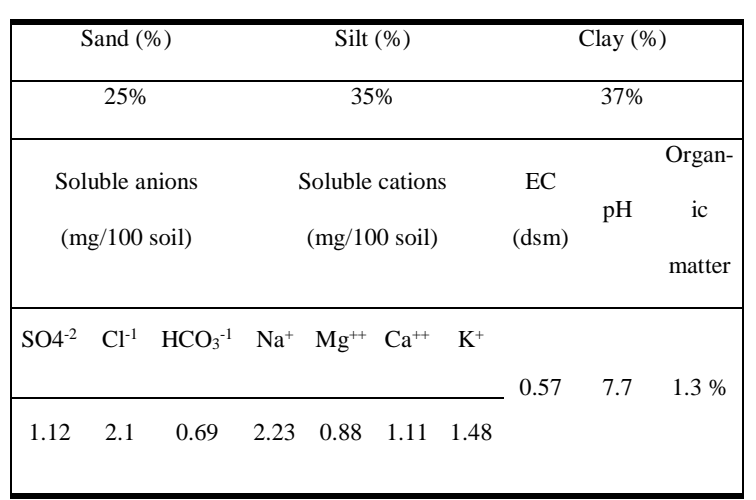

Seeds were sown in the bed on the $1^{\text {st }}$ October at both seasons, after 45 days from sowing seedlings were transplanted to pots of $30 \mathrm{~cm}$ in diameter, each pot contained $10 \mathrm{~kg}$ clay soil and they were divided into three main groups. The first group contains a clay soil with recommended chemical fertilizers (as control). The second group contains a mixture of clay soil with $0.96 \mathrm{~g}$ feldspar/ pot (contain $11 \% \mathrm{~K}_{2} \mathrm{O}$ ) and $1.94 \mathrm{~g}$ rock phosphate/ pot (contain $32 \% \mathrm{P}_{2} \mathrm{O}_{5}$ ). The third groupcontains a mixture of clay soil with $0.96 \mathrm{~g}$ feldspar / pot.

Each treatment was divided into three subgroups at randomized experiment, the first, second and third subgroups contained the seedlings of Ruta graveolens L. inoculated with biological potassium phosphorous fertilizer or biological potassium fertilizer (Silicate bacterium) with 25, 50 and $100 \mathrm{~g} /$ litter respectively and the treatments were as follows:

- Treatments of Biological Phosphorous Potassium Fertilizer

1- Control (recommended chemical fertilizers)

2- 25g/ L of Biological

Phosphorous Potassium

Fertilizer

3- 50g/ L of Biological

Phosphorous Potassium

Fertilizer

+ Rock phosphate \& Feldspar

4- 100g/ L of Biological

Phosphorous Potassium

Fertilizer

- Treatments of Biological Potassium Fertilizer

1- Control (recommended chemical fertilizers)

2- 25g/ L of Biological Potassium Fertilizer

+ Feldspar
3- 50g/ L of Biological Potassium Fertilizer

4- 100g/ L of Biological Potassium Fertilizer

Each treatment contained three replicates, each replicate contained five pots and each pot contained three plants. All agriculture practices operations other than experimental treatments were don according to the recommendations of Ministry of Agriculture, Egypt.

Biological potassium phosphorous fertilizer and biological potassium fertilizer (Silicate bacterium) obtained from Hebei institute of microbiology, Hebei province, P.R. China.

\section{Vegetative growth parameters}

At flowering stage, plant height $(\mathrm{cm})$, branches number/plant, fresh and dry weights of different parts i.e. leaves, stems and roots (g/plant) were determined.

\section{Chemical analysis} mined

The following chemical analyses were deter-

\section{Essential oil}

Fresh herb at harvesting time (100g) was subjected to hydro distillation for $3 \mathrm{~h}$ using a Clevenger type apparatus (Clevenger, 1928). Constituents of essential oil were determined by gas-liquid chromatography in the treatments which gave the highest yield of essential oil by g/plant $(50 \mathrm{~g} / \mathrm{L}$ and $100 \mathrm{~g} / \mathrm{L}$ of biological potassium phosphorous fertilizer, $50 \mathrm{~g} / \mathrm{L}$ and $100 \mathrm{~g} / \mathrm{L}$ of biological potassium fertilizer) and control treatment. The chromatograph (Model Perkin Elmer 3920B) was equipped with a thermal conductivity detector and a $2.0 \mathrm{~m} \mathrm{X}$ $0.3 \mathrm{~cm}$ column packed with 10 percent Carbwax $20 \mathrm{M}$ on $80 / 100$ Chromsorb WAW and using hydrogen at $0.5 \mathrm{~cm}^{3} / \mathrm{s}$ as the carrier gas. The column temperature was $130{ }^{\circ} \mathrm{C}$ and detector and injector temperature were $200{ }^{\circ} \mathrm{C}$. Constituents were identified by retention times and by connection with known structures.

\section{Total flavonoides}

Total flavonoides were determined in dried leaves of Ruta graveolens L. according to Zhishen et al (1999). 


\section{Total nitrogen and phosphorous}

Total nitrogen and phosphorous in dry leaves, stems and roots of Ruta graveolens L, were determined according to the methods of the Association of Official Agricultural Chemistry (A.O.A.C.) 1970 .

\section{Potassium}

Potassium content in leaves, stems and roots of Ruta graveolens L. was determined by photometrically methods according to Brown and Lilleland (1945).

\section{Micronutrients}

The leaves, stems and roots samples of Ruta graveolens $\mathrm{L}$ were dried, ground and $\mathrm{Cu}, \mathrm{Zn}, \mathrm{Fe}$, extracted by acid digestion technique (Cottenie $\boldsymbol{e t}$ al 1982), concentrations were determined by atomic absorption spectrophotometer BerkenElmer (Gonzalez et al 1973).

\section{Statistical analysis}

The obtained data were statistically analyzed for the mean of two successive seasons according to the procedure outlined by Snedecor and Cochran (1990).

\section{RESULTS AND DISCUSSION}

Effect of biological potassium phosphorous fertilizer with rock phosphate and /or feldspar

\section{Vegetative growth characters}

The application of biological potassium phosphorous fertilizer with feldspar and rock phosphate were more effective in enhancing vegetative growth values such as plant height $(\mathrm{cm})$, branches number/plant, fresh and dry weights of different parts i.e. leaves, stems and roots (g/plant) in comparison with the addition of chemical fertilizers (Table 2). The highest values of vegetative growth parameters were resulted from the treatment of $50 \mathrm{~g} / \mathrm{L}$ of biological potassium phosphorous fertilizer with feldspar \& rock phosphate compared with other treatments. The increment in plant height, branches number, fresh and dry weight of plant were recorded to $32.9 \%, 98.4 \%, 113.1 \%$ and $120.8 \%$ respectively as a resulted of $50 \mathrm{~g} / \mathrm{L}$ of biological potassium phosphorous fertilizer compared with control treatment.

The increment of vegetative growth characters may be due to, biological potassium phosphorous fertilizer increase the available phosphorous, potassium and some micronutrients which gave a good vegetative growth characters (Sheng et al 2003 and Khalid 2004). Also these results confirmed by Strzelezyk and Pokojska (1984), who reported that, this increment of vegetative growth values might be due to the stimulation effect of biological potassium phosphorous fertilizer on the plant growth metabolism such as plant growth promoting substances.

\section{Essential oil content}

The application of biological potassium phosphorous fertilizer with feldspar as a source of potassium \& rock phosphate as a source of phosphorous resulted higher values of essential oil percentage or $\mathrm{ml} /$ plant in comparison with control one (Table 3).

The highest significant increment of essential oil percentage or $\mathrm{ml} /$ plant were obtained from the treatment with $50 \mathrm{~g} / \mathrm{L}$ of biological potassium phosphorous fertilizer with feldspar \& rock phosphate compared with other treatments.

Table 2. Effect of biological potassium phosphorous fertilizer with rock phosphate and feldspar on the vegetative growth characters of Ruta graveolens L plants (Mean values of two successive seasons).

\begin{tabular}{|c|c|c|c|c|c|c|c|c|c|c|c|}
\hline \multicolumn{2}{|c|}{ Treatments } & \multirow[b]{2}{*}{$\begin{array}{l}\text { Plant } \\
\text { height } \\
(\mathrm{cm})\end{array}$} & \multirow[b]{2}{*}{$\begin{array}{c}\text { Branches } \\
\text { number/ } \\
\text { plant }\end{array}$} & \multirow[b]{2}{*}{$\begin{array}{l}\text { Leaf fresh } \\
\text { weight } \\
\text { (g/plant) }\end{array}$} & \multirow[b]{2}{*}{$\begin{array}{l}\text { Stem fresh } \\
\text { weight } \\
\text { (g/plant) }\end{array}$} & \multirow[b]{2}{*}{$\begin{array}{c}\text { Root fresh } \\
\text { weight } \\
\text { (g/plant) }\end{array}$} & \multirow[b]{2}{*}{$\begin{array}{c}\text { Total fresh } \\
\text { weight } \\
\text { (g/plant }\end{array}$} & \multirow[b]{2}{*}{$\begin{array}{l}\text { Leaf dry } \\
\text { weight } \\
\text { (g/plant) }\end{array}$} & \multirow[b]{2}{*}{$\begin{array}{l}\text { Stem dry } \\
\text { weight } \\
\text { (g/plant) }\end{array}$} & \multirow[b]{2}{*}{$\begin{array}{c}\text { Root } \\
\text { dry } \\
\text { weight } \\
\text { (g/plant) }\end{array}$} & \multirow[b]{2}{*}{$\begin{array}{c}\text { Total } \\
\text { dry } \\
\text { weight } \\
\text { (g/plant) }\end{array}$} \\
\hline $\begin{array}{l}\text { Biological } \\
\text { Potassium } \\
\text { Phosphorou } \\
\text { Fertilizer }\end{array}$ & & & & & & & & & & & \\
\hline+ & Control & 26.1 & 6.4 & 5.8 & 6.9 & 2.6 & 15.3 & 1.4 & 2.6 & 0.8 & 4.8 \\
\hline $\begin{array}{l}\text { Rock } \\
\text { Phos- }\end{array}$ & $25 \mathrm{~g} / \mathrm{L}$ & 30.5 & 8.9 & 7.0 & 9.1 & 3.8 & 19.9 & 1.8 & 3.6 & 1.1 & 6.5 \\
\hline phate \& & $50 \mathrm{~g} / \mathrm{L}$ & 34.7 & 12.7 & 12.7 & 12.5 & 7.4 & 32.6 & 3.2 & 5.2 & 2.2 & 10.6 \\
\hline Feldspar & $100 \mathrm{~g} / \mathrm{L}$ & 28.9 & 9.0 & 9.0 & 8.7 & 6.3 & 24.0 & 2.2 & 3.5 & 1.9 & 7.6 \\
\hline \multicolumn{2}{|c|}{ L.S.D. at 0.05} & 1.79 & 0.91 & 0.6 & 0.97 & 0.41 & 1.16 & 0.1 & 0.08 & 0.05 & 0.07 \\
\hline
\end{tabular}


Table 3. Effect of biological potassium phosphorous fertilizer with rock phosphate and feldspar on the essential oil and total flavonoides content of Ruta graveolens L plants (Mean values of two successive seasons).

\begin{tabular}{|c|c|c|c|c|}
\hline \multicolumn{2}{|c|}{ Treatments } & \multirow[b]{2}{*}{$\begin{array}{l}\text { Essential oil } \\
\text { percentage }\end{array}$} & \multirow[b]{2}{*}{$\begin{array}{l}\text { Essential oil } \\
\text { (g/plant) }\end{array}$} & \multirow[b]{2}{*}{$\begin{array}{c}\text { Total flavo- } \\
\text { noides } \\
(\mathrm{mg} / \mathrm{g})\end{array}$} \\
\hline $\begin{array}{l}\text { Biological } \\
\text { Potassium P } \\
\text { Fertilizer }\end{array}$ & horous & & & \\
\hline+ & Control & 0.075 & 0.011 & 35.0 \\
\hline Rock & $25 \mathrm{~g} / \mathrm{L}$ & 0.093 & 0.019 & 41.0 \\
\hline Phosphate & $50 \mathrm{~g} / \mathrm{L}$ & 0181 & 0.059 & 52.0 \\
\hline \& Feldspar & $100 \mathrm{~g} / \mathrm{L}$ & 0.082 & 0.020 & 46.0 \\
\hline \multicolumn{2}{|c|}{ L.S.D. at 0.05} & 0.0085 & 0.007 & 2.02 \\
\hline
\end{tabular}

This treatment increased essential oil percentage and oil yield (ml /plant) by $141.3 \%$ and $436.4 \%$ respectively compared with control treatment. The increase in the essential oil content may be due to the effect of biological potassium phosphorous fertilizer which increasing the available phosphorous, potassium and some micronutrients (Sheng et al 2003) which increase the essential oil content as shown in some aromatic plants such as anise, coriander and sweet fennel (Khalid 1996).

\section{Total flavonoides}

Data in (Table 3) indicated that, various levels of biological potassium phosphorous fertilizer with feldspar \& rock phosphate treatments overcame the control treatment and improved the accumulation of total flavonoides. The highest values of total flavonoides was recorded with $50 \mathrm{~g} / \mathrm{L}$ of biological potassium phosphorous fertilizer with feldspar \& rock phosphate, which significantly increased total flavonoides content $(\mathrm{mg} / \mathrm{g})$ and reached to $48.6 \%$ over control treatment. These results are confirmed with of Piccaglia $\boldsymbol{e t}$ al (1997), who demonstrated that, the ecological factors change total flavonoides content of Calendula officinalis L. plant.

\section{Chemical constituents of essential oil}

The qualitative and quantitative analysis of main constituents of essential oil of Ruta graveolens L plants treated with feldspar \& rock phosphate under biological potassium phosphorous fertilizer (Table 4) revealed that, the main con- stituent was found for control treatment was Undecan-2-one which formed $54.59 \%$, the second major compound was Nonan-2-one which recorded $15.25 \%$. The third and fourth order of compounds found in a fewer amount were Methyl salicylate and Linalol 1.5 giving $6.9 \%$ and $3.35 \%$ respectively. Moreover the identified compound composed 94.06 of the total compounds of Ruta graveolens L plants while the unidentified compounds accounted about $5.94 \%$. The recorded data appeared that, the identified compounds were markedly affected by various biological potassium phosphorous fertilizer levels.

Table 4. Effect of biological potassium phosphorous fertilizer with rock phosphate and feldspar on the main constituents of essential oil extracted from Ruta graveolens L plants.

\begin{tabular}{|cccc|}
\hline & \multicolumn{3}{c}{ Biological Potassium } \\
phosphorous Fertilizer \\
identification & \multicolumn{3}{c|}{ Treatments } \\
\cline { 2 - 4 } & Control & $50 \mathrm{~g} / \mathrm{L}$ & $100 \mathrm{~g} / \mathrm{L}$ \\
\hline$\alpha$-Pinene & 0.19 & 0.22 & 0.08 \\
Camphene & 0.26 & 0.08 & 2.80 \\
$\beta$-Pinene & 0.06 & 0.70 & 0.31 \\
Nonan-2-one & 15.25 & 14.63 & 12.85 \\
Linalool 1.5 & 3.35 & 2.71 & 1.31 \\
Phenyl ethyl alcohol & 0.19 & 0.37 & 2.40 \\
Nonan-2-ol & 0.15 & 2.40 & 4.78 \\
Octanoic acid & 2.50 & 5.57 & 0.24 \\
Methyl salicylate & 6.90 & 0.23 & 0.34 \\
Decan-2-one & 0.24 & 1.45 & 0.85 \\
Undecan-2-one & 54.59 & 51.51 & 51.55 \\
Undecan-2-ol & 0.41 & 0.31 & 0.34 \\
Dodec-2-ene & 1.88 & 2.03 & 3.86 \\
Tridecane & 1.63 & 1.57 & 0.37 \\
Decyl-2-acetate & 0.31 & 2.54 & 2.01 \\
Dodecan-2-one & 2.08 & 0.22 & 0.45 \\
Tridecan-2-one & 0.19 & 0.25 & 1.63 \\
$\alpha$-Copaene & 1.50 & 0.32 & 0.60 \\
$\beta$-Caryophyllene & 0.39 & 0.15 & 0.22 \\
$\alpha$-Humulene & 0.12 & 0.16 & 0.13 \\
$\gamma$-Cadinene & 0.16 & 0.12 & 0.15 \\
Hexadecane & 0.20 & 0.17 & 0.12 \\
$\alpha$-Eudesmol & 0.14 & 0.25 & 1.23 \\
Pentadecan-2-one & 0.11 & 0.14 & 0.21 \\
Heptadecane & 0.86 & 0.22 & 0.10 \\
Pentadecanol & 0.15 & 0.10 & 3.66 \\
Hexadecanol & 0.11 & 0.10 & 0.35 \\
Xanthotoxin & 0.14 & 0.67 & 0.13 \\
\hline Total identified & 94.06 & 89.19 & 93.07 \\
\hline
\end{tabular}


Biological potassium phosphorous fertilizer at 50 and $100 \mathrm{~g} / \mathrm{L}$ with rock phosphate and feldspar decreased the components of Undecan-2-one and Nonan-2-one compared with the control treatment. Similar constituents of essential oil extracted from the aerial parts of Ruta graveolens L plants were also found by Feo et al 2002, on the same plant. The effect of different treatments on essential oil constituents may be due to its effect on enzymes activity and metabolism improvements.

\section{Mineral content}

Leaves, stems and roots PK content, significantly increased by increasing biological potassium phosphorous fertilizer levels with feldspar \& rock phosphate. (Table 5). The highest percentage of leaves, stems and roots $\mathrm{P} \& \mathrm{~K}$ content resulted from the treatment of $50 \mathrm{~g} / \mathrm{L}$ of biological potassium phosphorous fertilizer with feldspar \& rock phosphate compared with other treatments. Nitrogen percentage of rue plant (Table 5) treated with various levels of biological potassium phosphorous fertilizer with feldspar \& rock phosphate appeared a marked decreased in various organs compared with control treatment. The lowest leaves, stems and roots $\mathrm{N}$ content obtained from the treatment of $25 \mathrm{~g} / \mathrm{L}$ of biological potassium phosphorous fertilizer with feldspar \& rock phosphate compared with other treatments and control treatment.

Data of available elements show that, there are significantly increase in the DTPA-extractable of $\mathrm{Zn}, \mathrm{Cu}$ and $\mathrm{Fe}$ in leaves, stems and roots by addition of biological potassium phosphorous fertilizer with feldspar \& rock phosphate compared with the control treatment (Table 5).

The decrease of $\mathrm{N}$ content due to application of biological potassium phosphorus fertilizer could be attributed to the depletion of $\mathrm{N}$ nutrient in building new tissues (Nijjar, 1985). The increase of $\mathrm{P}, \mathrm{K}, \mathrm{Zn}, \mathrm{Cu}$ and $\mathrm{Fe}$ due to, biological potassium phosphorous fertilizer increases the available phosphorous potassium and some micronutrients for plants (Khalid 2004 and Sheng $\boldsymbol{e t}$ al 2003).

\section{Effect of biological potassium fertilizer and feldspar}

\section{Vegetative growth characters}

The effect of the different treatments of biological potassium fertilizer with feldspar on the vegetative growth characters i.e. plant height $(\mathrm{cm})$, branches number/plant, fresh and dry weights of different organs such as leaves, stems and roots (g/plant) is presented in Table (6). Generally, increasing biological potassium fertilizer levels up to $50 \mathrm{~g} / \mathrm{L}$ progressively increased significant the vegetative growth characters compared with control treatment .Thus, the highest values of vegetative growth characters were recorded with treatments of $50 \mathrm{~g} / \mathrm{L}$ of biological potassium fertilizer with feldspar which increased mean values of plant height $(\mathrm{cm})$, number of branches/plant fresh and dry weights of whole plant (g/plant) recorded to $18.4 \%, 50 \%, 65.4 \%$ and $62.5 \%$.

These results are agreement with Sheng et al (2003) who observed that, silicate-dissolving bacteria promote plant growth. In addition, Silicate bacterium or biological potassium fertilizer can prevention and control of plant diseases, so plants gave a good growth characters (Subba Rao, 1984).

\section{Essential oil content}

Biological potassium fertilizer significantly increased herbal essential oil percentage or $\mathrm{ml} /$ plant with feldspar treatments compared with the control treatment (Table 7). The highest values of herbal essential oil percentage or $\mathrm{ml} /$ plant were resulted from the treatments of $50 \mathrm{~g} / \mathrm{L}$ of biological potassium fertilizer with feldspar which increased essential oil percentage and oil yield (ml/plant) by $154.6 \%$ and $456.3 \%$ respectively compared with control. These results may be due to, silicate bacterium or biological potassium fertilizer which can activate the fixed potassium for plant nutrition (Subba Rao, 1984). and increase the essential oil content (Somida 2002 ) on marigold plants.

\section{Total flavonoides}

Application various levels of biological potassium fertilizer with feldspar increased total flavonoides content in compared with the control treatment. The highest value of total flavonoides was resulted from the treatment of $50 \mathrm{~g} / \mathrm{L}$ of biological potassium fertilizer with feldspar that recorded $34.6 \%$ over the control treatment (Table 7). These results are confirmed with Piccaglia et al (1997), working on Calendula officinalis L. plant and demonstrated that, the ecological factors change total flavonoides content. 
Table 5. Effect of biological potassium phosphorous fertilizer with rock phosphate and feldspar on the nutrient content $(\mathrm{N}, \mathrm{P}, \mathrm{K}, \mathrm{Fe}, \mathrm{Zn}$ and $\mathrm{Cu}$ ) of Ruta graveolens $\mathrm{L}$ plants (Mean values of two successive seasons)

\begin{tabular}{|c|c|c|c|c|c|c|c|c|c|c|c|c|c|c|c|c|c|c|c|}
\hline 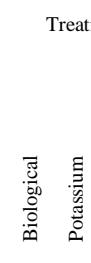 & 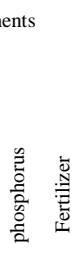 & \multicolumn{3}{|c|}{ Percentage } & \multicolumn{3}{|c|}{ ppm } & \multicolumn{3}{|c|}{ Percentage } & \multicolumn{3}{|c|}{ ppm } & \multicolumn{3}{|c|}{ Percentage } & \multicolumn{3}{|c|}{ ppm } \\
\hline & Control & 3.6 & 0.25 & 2.6 & 136 & 137 & 7.8 & 2.3 & 0.42 & 2.4 & 122 & 130 & 7.8 & 3.7 & 0.25 & 136 & 240 & 130 & 7.8 \\
\hline+ & $25 \mathrm{~g} / \mathrm{L}$ & 2.2 & 0.26 & 2.8 & 156 & 140 & 8.1 & 2.0 & 0.43 & 2.7 & 132 & 135 & 8.8 & 2.3 & 0.26 & 156 & 255 & 141 & 8.1 \\
\hline L.S.D. & 0.05 & 0.08 & 0.001 & 0.002 & 3.9 & 1.1 & 0.08 & 0.06 & 0.001 & 0.001 & 2.19 & 1.2 & 0.06 & 0.06 & 0.002 & 0.002 & 2.36 & 1.4 & 0.04 \\
\hline
\end{tabular}

Table 6. Effect of biological potassium fertilizer and feldspar on the vegetative growth characters of Ruta graveolens L plant (Mean values of two successive seasons).

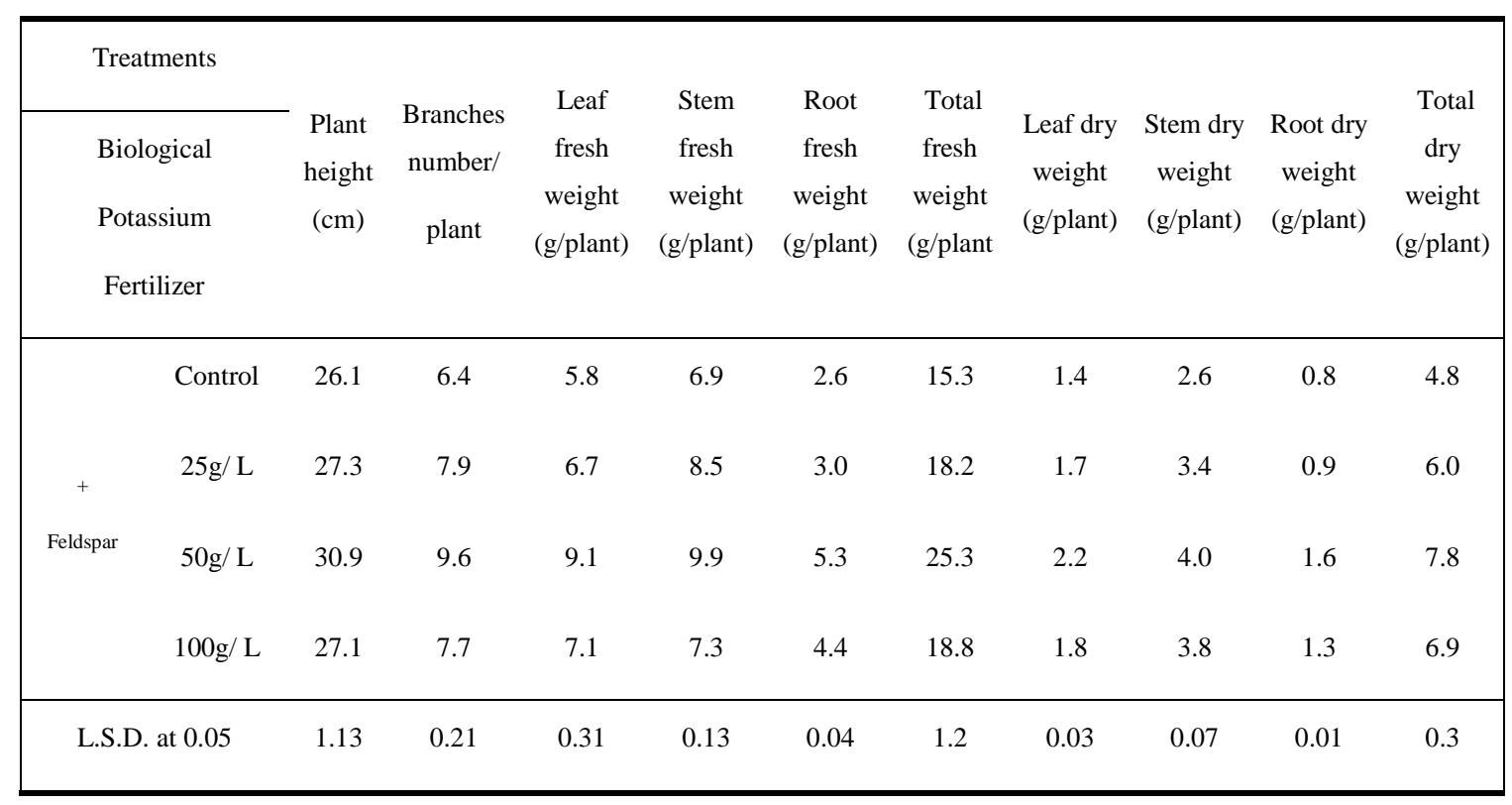


Table 7. Effect of biological potassium fertilizer and feldspar on the essential oil and total flavonoides content ofRuta graveolens $\mathrm{L}$ plants (Mean values of two successive seasons).

\begin{tabular}{|c|c|c|c|c|}
\hline \multicolumn{2}{|c|}{ Treatments } & \multirow{2}{*}{$\begin{array}{c}\text { Essential } \\
\text { oil } \\
\text { percentage }\end{array}$} & \multirow{2}{*}{$\begin{array}{c}\text { Essential } \\
\text { oil } \\
\text { (g/plant) }\end{array}$} & \multirow{2}{*}{$\begin{array}{c}\text { Total flavo- } \\
\text { noides } \\
(\mathrm{mg} / \mathrm{g})\end{array}$} \\
\hline $\begin{array}{l}\text { Biolo } \\
\text { Potass } \\
\text { Fertili }\end{array}$ & & & & \\
\hline \multirow{4}{*}{$\begin{array}{c}+ \\
\text { Feld- } \\
\text { spar }\end{array}$} & Control & 0.075 & 0.011 & 35.0 \\
\hline & $25 \mathrm{~g} / \mathrm{L}$ & 0.091 & 0.017 & 39.0 \\
\hline & $50 \mathrm{~g} / \mathrm{L}$ & 0.191 & 0.048 & 47.0 \\
\hline & $100 \mathrm{~g} / \mathrm{L}$ & 0.084 & 0.019 & 38.0 \\
\hline \multicolumn{2}{|c|}{ L.S.D. at 0.05} & 0.009 & 0.004 & 2.49 \\
\hline
\end{tabular}

\section{Chemical constituents of essential oil}

Results in Table (8) showed the effect of biological potassium fertilizer with feldspar on the main chemical constituents of essential oil extracted from Ruta graveolens L plants. The main constituents were found to be Undecan-2-one (54.59 $\%)$, and Nonan-2-one (15.25\%) for control treatment as reported before. Also the identified compounds of essential oil were affected by biological potassium fertilizer with feldspar. Treatments of $50 \mathrm{~g} / \mathrm{L}$ and $100 \mathrm{~g} / \mathrm{L}$ biological potassium fertilizer with feldspar decreased the two main components compared with the control treatment.

The decreased percentage of these components reached $7.5 \%$ and $8 \%$ compared with control treatment, while the total identified constituents decreased by $7.3 \%$ and $9.9 \%$ in comparison with control treatment for both levels $50 \mathrm{~g} / \mathrm{L}$ and $100 \mathrm{~g} / \mathrm{L}$ respectively.

Feo et al (2002) also found the same obtained constituents of essential oil extracted from the aerial parts of Ruta graveolens L plants. The effect of different treatments on essential oil constituents may be due to its effect on enzymes activity and metabolism improvements.
Table 8. Effect of biological potassium fertilizer and feldspar on the main constituents of essential oil extracted Ruta graveolens L plants.

\begin{tabular}{|c|c|c|c|}
\hline \multirow[t]{2}{*}{$\begin{array}{l}\text { Compound } \\
\text { identification }\end{array}$} & \multicolumn{3}{|c|}{$\begin{array}{c}\text { Biological Potassium } \\
\text { Fertilizer } \\
\text { Treatments } \\
\end{array}$} \\
\hline & Control & $50 \mathrm{~g} / \mathrm{L}$ & $100 \mathrm{~g} / \mathrm{L}$ \\
\hline$\alpha$-Pinene & 0.19 & 0.17 & 0.09 \\
\hline Camphene & 0.26 & 0.24 & 0.05 \\
\hline$\beta$-Pinene & 0.06 & 0.07 & 0.30 \\
\hline Nonan-2-one & 15.25 & 13.66 & 7.63 \\
\hline Linalool 1.5 & 3.35 & 0.17 & 2.84 \\
\hline Phenyl ethyl alcohol & 0.19 & 3.6 & 0.28 \\
\hline Nonan-2-ol & 0.15 & 0.19 & 1.89 \\
\hline Octanoic acid & 2.50 & 4.23 & 4.37 \\
\hline Methyl salicylate & 6.90 & 0.27 & 0.21 \\
\hline Decan-2-one & 0.24 & 1.39 & 0.35 \\
\hline Undecan-2-one & 54.59 & 50.38 & 50.16 \\
\hline Undecan-2-ol & 0.41 & 1.94 & 0.35 \\
\hline Dodec-2-ene & 1.88 & 0.39 & 2.30 \\
\hline Tridecane & 1.63 & 1.65 & 1.96 \\
\hline Decyl-2-acetate & 0.31 & 0.60 & 0.36 \\
\hline Dodecan-2-one & 2.08 & 0.17 & 2.08 \\
\hline Tridecan-2-one & 0.19 & 0.13 & 0.50 \\
\hline$\alpha$-Copaene & 1.50 & 0.11 & 2.01 \\
\hline$\beta$-Caryophyllene & 0.39 & 1.21 & 0.85 \\
\hline$\alpha$-Humulene & 0.12 & 0.16 & 0.24 \\
\hline$\gamma$-Cadinene & 0.16 & 0.09 & 0.20 \\
\hline Hexadecane & 0.20 & 0.17 & 0.13 \\
\hline$\alpha$-Eudesmol & 0.14 & 3.78 & 1.62 \\
\hline Pentadecan-2-one & 0.11 & 0.07 & 0.19 \\
\hline Heptadecane & 0.86 & 0.30 & 0.13 \\
\hline Pentadecanol & 0.15 & 0.15 & 0.48 \\
\hline Hexadecanol & 0.11 & 1.82 & 0.15 \\
\hline Xanthotoxin & 0.14 & 0.17 & 3.88 \\
\hline Total identified & 94.06 & 87.28 & 85.6 \\
\hline
\end{tabular}

\section{Mineral content}

Leaves, stems and roots $\mathrm{N}$ content, significantly decreased by increasing biological potassium fertilizer levels with feldspar (Table 9). On the other hand, the content of $\mathrm{P}$ and $\mathrm{K}$ of different organs recorded a marked increment with various levels of biological potassium fertilizer with feldspar compared with control treatment. The highest percentage $\mathrm{P}$ and $\mathrm{K}$ content resulted from the medium level $(50 \mathrm{~g} / \mathrm{L})$ of biological potassium fertilizer with feldspar for different organs. 
Table 9. Effect of biological potassium fertilizer and feldspar on the nutrient content (N, P, K, Fe, Zn and $\mathrm{Cu}$ ) of Ruta graveolens L plants (Mean value of two successive seasons).

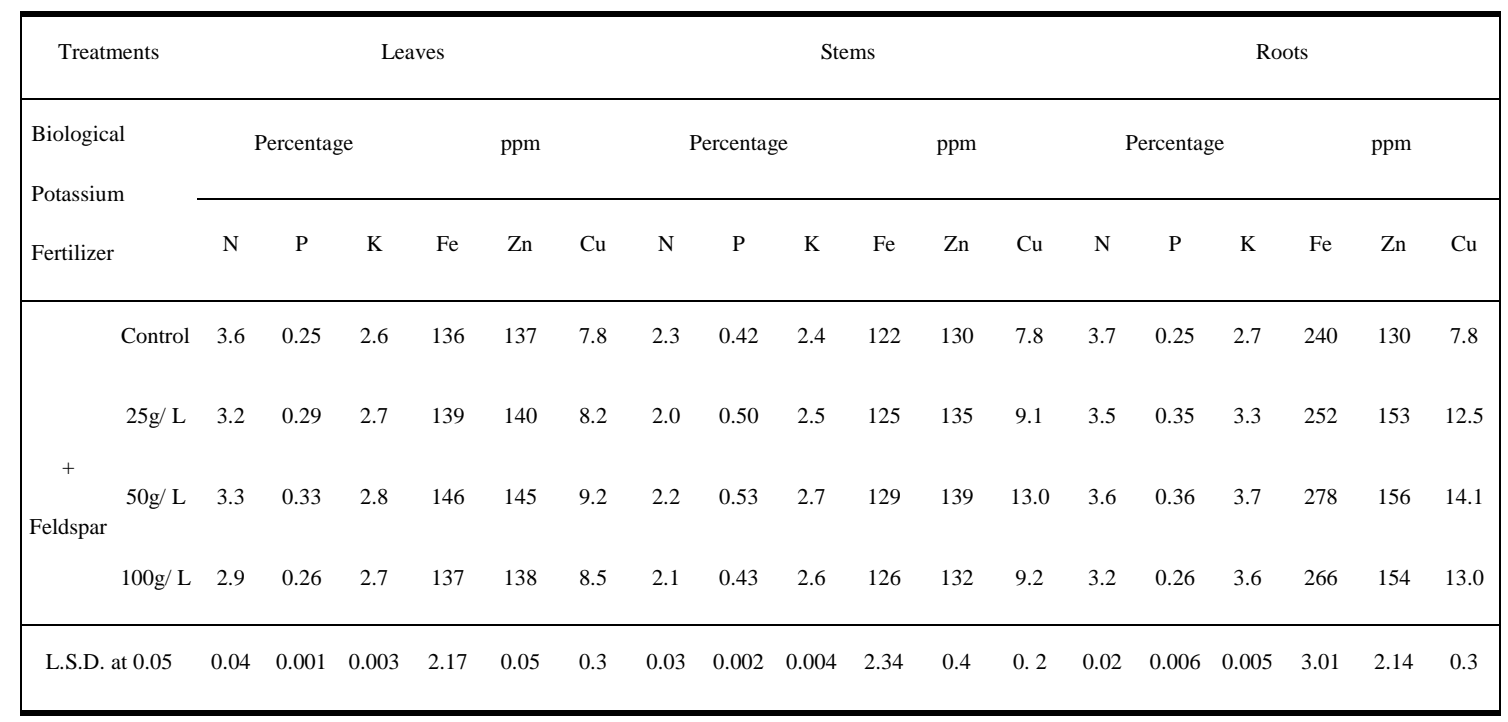

Meanwhile, the highest mean values of $\mathrm{N}$ content of leaves, stems and roots obtained from the control treatment compared with other treatments.

Data of available microelements of rue plants showed that, there are significantly increase in the DTPA-extractable of $\mathrm{Fe}, \mathrm{Zn}$ and $\mathrm{Cu}$ in leaves, stems and roots by addition various levels of biological potassium fertilizer with feldspar compared with the control treatment (Table 9). The highest accumulation for different micro elements were recorded with applied $50 \mathrm{~g} / \mathrm{L}$ biological potassium fertilizer with feldspar for the various organs.

The decrease of $\mathrm{N}$ content due to application of biological potassium fertilizer could be attributed to the depletion of $\mathrm{N}$ nutrient in building new tissues (Nijjar 1985). Otherwise, the increase of $\mathrm{P}, \mathrm{K}, \mathrm{Zn}, \mathrm{Cu}$ and Fe content may be due to, the adding biological potassium fertilizer caused an increase in the available phosphorous potassium and some micronutrients for plants (Sheng et al 2003).

\section{CONCLUSION}

From above mentioned results, it could be concluded that, we can use natural products as a source of some important elements for rue plant such as rock phosphate as a source of phosphorous and feldspar mica as a source of potassium with biological potassium phosphorous fertilizer or biological potassium fertilizer (Silicate bacterium) of $50 \mathrm{~g} / \mathrm{L}$ instead of the chemical fertilizes hence it caused a marked promotion for various growth characters and chemical composition of rue plants.

\section{REFERENCES}

Aliotta, G.; G. Caero; V. De Feo and R. Sacchi (1994). Potential allelochemicals from Ruta graveolens L. and their action on radish seeds. J. Chem. Eco. 20: 2761-2775.

Aliotta, G.; G. Caero; V. De Feo; A.D. Palumbo and S. Strumia (1995). Inhibition of weeds germination by a simple infusion of rue. Proceedings of Twenty-second Annual Meeting of Plant Growth Regulation Soc. of Amer. 11: 93-97.

Aliotta, G.; G. Caero; V. De Feo; A.D. Palumbo and S. Strumia (1996). Infusion of rue for control of purslane weed: biological and chemical aspects. Allelopa J. 3: 207-216.

Association of Official Agriculture Chemistry (A.O.A.C.) (1970). Official Methods Analysis, pp. 159-211. 10 ${ }^{\text {th }}$ Ed. Washington, D.C.

Biswas, D.R. and G. Narayanasamy (2002). Mobilization of phosphorous from rock phosphate through compositing using crop residue. Fertiliser

News. 47 (3): 53-56.

Brown, J.D. and O. Lilleland (1945). Rapid determination of potassium in plant extracts by flame-photometry. Proc. Amer. Sco. Hort. Sci. 48: 341-446.

Clevenger, J.F. (1928). Apparatus for determination of essential oil. J. Amr. Pharm. Assoc.17: 346-349. 
Cottenie, A.; M. Verloo; L. Kiekens; G. Velghe and R. Camerlynck (1982). Chemical Analysis of Plant and Soil. pp. 100-129. Laboratory of Analytical and Agrochemistry, State Univ.Ghent. Belgium.

El-Gamal, A.M. (1996). Response of Potatoes to phosphorous fertilizer levels and phosphorene biofertilizer in the newly reclaimed areas. Assiut J. Agric. Sci. 27 (2): 77-87.

Espinnosa, L.E.; C.A. Sanchez and T.J. Schueneman (1993). Celery yield responds to potassium rate. Hort. Sci., 28:1125-1128.

Feo, V.D.; F.D. Simone and F. Senatore (2002). Potential allelochemicals from the essential oil of Ruta graveolens. Phytochemistry, 61: 573-578.

Goldstein, A.H. (1995). Recent progress in understanding the molecular genatics and biochemistry of calcium phosphate solubilization by gram negative bacteria. Biol. Agric. Hortic. 12: 185-193.

Gomaa, A.M.H. (1989). Biofertilizers for Increasing of Crop Production. pp. 49-57. M.Sc. Thesis. Fac. Agric.Cairo Univ., Egypt.

Gonzalez, C.; M. Banez; M. Wylle and J. Sole (1973). La Nutricion Miniral de le Vegetables. p. 134, Facultad de Agronomia, Universidad Catulica de Chile.

Harborne, J.B. and M. Boardley (1983). Identification of two gossypetin monomethyl ethers as yellow flower pigments in the Rutaceae. $\mathbf{Z}$. Naturforsch. 38c: 148 - 150.

Jackson, M.L. (1973). Soil Chemical Analysis. pp. 200-250. Prentice Hall Indian, Private Limited. M.97, Connght Citrus, New Delhi-1.

Khalid, Kh. A. (1996). Effect of Fertilization on The Growth, Yield and Chemical Composition of Some Medicinal Umbelleferous Plants. pp.15. M.Sc. Thesis, Fac. Agric., Al-Azhar Univ., Cairo. Egypt.

Khalid, Kh.A. (2004). Response of white mustard (Sinapis alba L.) plants to calcium superphosphate and phosphorene under calcareous soil conditions. Arab Univ. J. Agric. Sci., 12 (2): 735-747.

Nijjar, G.S. (1985). Nutrition of Fruit Trees. pp.53-78. (ed.) Mrs Usha Raj Kumar, Kalyani, New Delhi, India.
Piccaglia, R.; M. Marotti; G. Chiavari and N. Gandini (1997). Effect of harvesting date on the flavonoid and carotenoid content of marigold ( $\mathrm{Ca}$ lendula officinalis L). Flavor and Fragrance J. 12: 85-90.

Sheng, X.F.; L.Y. He and W.Y. Huang (2003). Conditions of releasing potassium by silicate dissolving bacteria strain NBT. Agric. Sci. 1 (6): 662-666.

Snedecor, G.W. and W.G. Cochran (1990). Statistical Methods. $11^{\text {th }}$ Ed. pp: 369-375. Iowa State College Press. Ames, Iowa, U.S.

Somida, E.G. (2002). Effect of Manure, Nitrogen and Potassium Fertilization on Growth, Flowering and Chemical Constituents of Marigold (Tagetes minuta L.) plants. pp. 52-75. Ph.D. Thesis Fac. Agric., Minia Univ., Egypt.

Strzelczyk, E. and B.A. Pokojska (1984). Production of auxins and gibberellen-like substances by microrrhizal fungi, bacteria and mycorrhizosphere of pine (Pinus silvestris). Plant and Soil. 81: 185-194.

Styriakova, I.; I. Styriak; I. Galko; D. Hradil and P. Bezdicka (2003). The release of iron bearing minerals and dissolution of feldspar by heterotrophic bacteria of Bacillus species. Ceramics Silicaty. 47(1): 20-26.

Subba Rao, N.S. (1984). Biofertilizer in Agriculture. pp. 135-139. Oxford, IBH Publ. Co., New- Delhi, India.

Vincenzo, D.F.; F.D. Simone and F. Senatore (2002). Potential allelochemicals from the essential oil of Ruta graveolens. Phytochemistry 61: 573-578.

Waterman, P.G. and M.F. Grundon (1985). Chemistry and Chemical Taxonomy of the Rutales. pp. 102-106. Academic Press. London:

Zahra, M. K.; M. Monib; S.I. Bbdel-Al and A. Heggo (1984). Significance of soil inoculation with silicate bacteria. Zentralblatt fur Mikrobiologie, 139 (5): 349-357.

Zhishen, J.; T. Mengcheng and W. Jianming (1999). The determination of flavonoides content in mulberry and their scavenging effects on superoxide radicals. Food Chemistry. 64: 555-559. 